\title{
Tópicos y preceptos de la épica en los preliminares de Fernando de Valverde y de Luis Antonio de Oviedo y Herrera*
}

\author{
Common Places and Precepts \\ in the Preliminary Matter in the Works \\ of Fernando de Valverde and Luis Antonio \\ de Oviedo y Herrera
}

ANDRÉs EICHMANN OEHRLI

\section{Carrera de Literatura}

Universidad Mayor de San Andrés

Av. 6 de Agosto 2118. La Paz, Bolivia

apeichmann@gmail.com

Orcid ID 0000-0002-2880-644X

Resumen: Me interesa recorrer los preliminares de las obras de Fernando de Valverde (Santuario de nuestra señora de Copacabana en el Perú, Lima 1641) y de Luis Antonio de Oviedo y Herrera (Vida de santa Rosa de Santa María, natural de Lima y patrona del Perú, poema heroico, Madrid 1711, escrito más de un decenio antes) y observar en ellos las nociones que sus autores manejan relacionadas con la poesía épica. Me he centrado en dos piezas de tema sacro que corresponden al último periodo de la poesía épica, lo cual permite reconocer el modo en que exploran algunos tópicos largamente discutidos desde el siglo XVI.

Palabras clave: Barroco. Poesía épica sacra. Fernando de Valverde. Luis Antonio de Oviedo y Herrera. Teoría de la épica. Paratextos.
Abstract: I should like to examine the preliminary texts of the works of Fernando de Valverde (Santuario de nuestra señora de Copacabana en el Perú, Lima 1641), and Luis Antonio de Oviedo y Herrera (Vida de santa Rosa de Santa María, natural de Lima y patrona del Perú, poema heroico, Madrid 1711, written some tens years earlier), with the aim of considering the ideas that the authors have as regards epic poetry. I have centred my study on two works of a religious nature that belong to the latter period of epic poetry, a fact that enables us to explore some of the topoi that were frequently used from the 16th century on.

Keywords: Baroque. Sacred Epic Poetry. Fernando de Valverde. Luis Antonio de Oviedo y Herrera. Epic Theory. Paratexts.

* Deseo expresar mi agradecimiento a los pares evaluadores del comité científico por sus excelentes observaciones y sugerencias. 


\section{INTRODUCCIÓN}

os dos poemas cuyos preliminares interesan aquí pertenecen a la épica sacra. El de Fernando de Valverde, publicado en 1641 en Lima, que consta de dieciocho cantos o "silvas" (en total, unos 25000 versos), se titula Santuario de nuestra Señora de Copacabana en el Perú. La acción se sitúa a orillas del lago Titicaca, y los principales protagonistas humanos son el pastor Graciano, que guía a otros dos, Adamio y Megerino (hijo de Adán el uno y de la reina de las erinias o furias el otro), junto con otros que van con ellos, a Copacabana para encontrarse con la Virgen María, designada como pastora, con el nombre de Amarili. En el camino (una suerte de peregrinación progresivamente purificadora) ocurren aventuras en las que se encuentran con algunos seres mitológicos, otros alegóricos, y también, por supuesto, otros que pertenecen al mundo sobrenatural cristiano, desde ángeles (incluidos los apócrifos Haniel y Baraquiel) hasta una paloma mística que lleva a los pastores una carta de Demosile, la sibila hispánica, etc. No falta un episodio que equivale a un descenso a los infiernos.

El poema de Oviedo y Herrera, Vida de santa Rosa de santa María, que consta de doce cantos en octavas reales, hace de la biografía de Santa Rosa de Lima un poema heroico. Después de la narración de la infancia y juventud de la santa, y sus victorias contra el tentador, se pasa (canto VI) a la descripción de los estragos del volcán Pichincha, y de ahí a la cueva del volcán donde el nigromántico Vilcaoma cuida a Yupangui, vástago real preso por decreto de Pachacámac. En el canto VII se narra el conciliábulo infernal en el que Luzbel decide dar la batalla contra santa Rosa y contra el Perú, para lo cual envía a dos mensajeros con sendos cometidos: la Ambición debe persuadir a Isabel de Inglaterra para que intente adueñarse del Perú; y b) la Traición irá a Holanda, hasta el "conde Mauricio" (Nassau, príncipe de Orange), quien más tarde, en el canto XI, despacharía al corsario "Jorge Espilberghen" (Joris van Spilbergen) para asolar la costa peruana. El mismo demonio sale por la boca del volcán y libera a Vilcaoma y a Yupangui para que este último levante a sus gentes contra los españoles. Vilcaoma (canto VIII) le relata a Yupangui episodios de la conquista hasta la muerte de "Atagualpa". El canto IX vuelve a santa Rosa, dando cuenta de algunas de sus experiencias místicas. Los tres cantos siguientes son de escenario guerrero, con episodios de lucha contra Drake, los dos Hawkins y Spilbergen (Yupangui finalmente no dio batalla sino que se retiró al Marañón). Ante el inminente desembarco del corsario holandés, santa Rosa se hace cargo de la defensa del Santísimo, a lo que se atribuye la retirada del enemigo. En los últimos tramos del canto XII se asiste al final de su vida y su entierro. 


\section{Antecedentes literarios}

Es necesario recordar que el origen de la épica sacra se sitúa en los siglos IV y V d.C. En lengua griega Nono de Panópolis escribió (además de Dionisíacas) una paráfrasis del Evangelio de san Juan de la que se conservan 3750 hexámetros de estilo homérico. En el ámbito latino hay una obra muy temprana, del año 330, Euangeliorum libri quattuor del hispano Juvenco, conocido en la Edad Media y en el Renacimiento como "el Virgilio cristiano" (Manchón Gómez 101). En el siglo siguiente, Celio Sedulio escribe el Carmen Paschale. Ambos poemas tienen en común el referir la vida, muerte y resurrección de Cristo. ${ }^{1}$ A estos se añade el poema Psichomachia de Prudencio (ca. 392), en el que combaten las virtudes contra los vicios.

Estos poemas fueron objeto de atención durante el Renacimiento. Se les dedicaron ediciones y comentarios y, a la vez, inspiraron a algunos poetas neolatinos. María José Vega y Lara Vilà indican que en el primer cuarto del siglo XVI

se redactan los comentarios más influyentes y durables de los poemas sacros tardoantiguos (como los de Nebrija sobre Prudencio y Sedulio) y en 1522 se imprimen los veinticuatro cantos de la Talichristia de Alvar Gómez de Ciudad Real [...]. Un decenio después se publicó la Christias de [Marco Girolamo] Vida, que conoció un notable éxito editorial en Italia, y durante la segunda mitad del siglo proliferaron las reimpresiones de pequeños libros de mano con colecciones de poemas sagrados épicos y elegíacos. (14)

Lara Vilà añade que la recuperación renacentista de esta épica tardoantigua de tema sacro, así como la creación de nuevas obras del mismo género en latín "es, ante todo, obra de humanistas para humanistas" (2010, 7, nota 16). Pero también es cierto que pronto vendrán, también, las creaciones de épica sacra en lengua vulgar. Esta, en sus comienzos, se centró en Jesucristo, y su principal asunto fue la Pasión: la primera pieza en castellano es la Christopatbia de Juan de Quirós, del año 1552, que Avalle-Arce califica de "pobre muestra épica” (Avalle-Arce 11). El tema de la Pasión de Cristo alcanza su máxima expresión épica unas décadas más tarde en América, con la Cbristiada de fray Diego

1. Sobre la Pasión de Cristo habría escrito una tragedia Gregorio de Nacianzo, en el mismo siglo IV (está en discusión la autoría). La edición de 1611, pp. 253-98 lo presenta en versión bilingüe, griega y latina. Posee una extensión de cerca de 2900 versos. 
de Hojeda. Explica Klaus Wagner que, conforme avanza el siglo XVII, "la temática de los poemas sacros se va ampliando" (Wagner 80) con desarrollos épicos del Génesis y, más tarde, con vidas de la Virgen, de san José y de otros santos. Vélez Marquina (2010, 68-69) hace una clasificación de 224 poemas épicos escritos entre 1550 y 1700; entre ellos figuran veintitrés uitae Christi y veintiocho vidas de santos.

Los dos poemas cuyos preliminares son objeto de este estudio entran, de maneras distintas, en esta tradición de la poesía épica sacra del periodo barroco. Valverde pretende haber creado "un nuevo linaje de poema, compuesto de épico y bucólico" (III 2r). Julia Sabena $(2014,118)$ advierte que tal linaje de poema no era del todo nuevo, sino que el camino ya lo había abierto Góngora con las Soledades; entre los elementos que Valverde toma del cordobés está la versificación en silvas. Será útil reconocer otros antecedentes, tanto para la poesía épica mariana como para la bucólica a lo divino. La primera epopeya de tema mariano parece ser el poema latino de Sannazaro titulado $D e$ partu Virginis, publicado en 1526 y traducido en octavas reales castellanas por Francisco de Aldana en 1591; y los primeros nacidos en lengua castellana son El Monserrate, de Cristóbal de Virués (1587) y Grandezas y excelencias de la Virgen nuestra señora, de Alonso Salas Barbadillo. Mazzotti (226), al revisar el catálogo ("fundamental aunque incompleto") de Frank Pierce (1968) registra otros once poemas épicos dedicados a la Virgen María, anteriores al de Valverde. Por otra parte, el desarrollo pastoril mariano comienza su andadura con la Primera parte de la clara Diana a lo divino, repartida en siete libros, de Bartolomé Ponce, publicada en Zaragoza en 1599. Este autor "convierte a Diana en la Virgen María y el amor profano en amor espiritual; otros protagonistas representan los vicios y las virtudes humanos; aparecen el Diablo vestido de mayoral [...], etc." (Wagner 77). En América tenemos por lo menos una novela pastoril a lo divino, Los sirgueros de la Virgen sin original pecado de Francisco Bramón, publicada en Nueva España en 1620; el poema de Valverde comparte con él el presentar a la Virgen María como objeto del amor y de la veneración de los pastores.

Por su parte, la Vida de Santa Rosa de Santa María de Luis Antonio de Oviedo y Herrera, una expresión tardía de la épica culta, es "uno de los pocos casos en los que el género épico consigue adecuar sus modelos a los propios de un género tan fijo como la hagiografía" (Vélez Marquina 2010, 40); y constituye otro caso híbrido, aunque de diversa índole que el anterior: el épicohagiográfico, que en esta ocasión afecta a la estructura narrativa. 
LOS PARATEXTOS DE AMBOS POEMAS

Como podremos ver, los paratextos pretenden ponerse al servicio de una "buena lectura" de los poemas, escritos por los autores mismos (los prólogos) o por sus "aliados"; constituyen parte de esa zona imprecisa de "transacción", como dice Genette, zona o "lieu privilégié d'une pragmatique et d'une stratégie, d'une action sur le public au service [...] d'un meilleur accueil du texte et d'une lecture plus pertinente -plus pertinente, s'entend, aux yeux de l'auteur et de ses alliés" (Genette 8).

De los prólogos y otros preliminares afirma María José Vega que "atestiguan el adensamiento y difusión de algunos lugares comunes sobre la escritura épica" y que "son capitales en el caso de la épica sacra" (Vega 105); precisamente, en estas páginas se intentará mostrar hasta qué punto la reflexión literaria adopta a menudo como sede este tipo de piezas, que a la vez permiten a sus autores adoptar también una posición en discusiones que rebasan lo meramente literario. Esto se verá en primer lugar, antes de abordar el contenido de los preliminares y de analizar el tratamiento que hacen de los tópicos.

\section{Épica y política}

Hasta tiempos bastante recientes se perdió de vista el enorme caudal de poesía épica producida en España y América en el Siglo de Oro. El trabajo pionero de Pierce (1968) permitió darse cuenta del largo olvido en que esta había caído. Poco a poco los estudiosos pararon mientes en la importancia que se le concedió en aquellos siglos. Explica Elizabeth Davis que en la matriz literaria de la época, todos los "géneros literarios de los siglos XVI y XVII se leen y se aprecian mejor contra un telón de fondo que ellos mismos invocan de varias maneras. Ese telón de fondo es la épica" (Davis 318). Indica Cacho Casal que fue "indudablemente el género poético más prestigioso" (5), y muestra que el apego a Aristóteles (para quien la tragedia es el género poético por excelencia) no impidió, en muchos teóricos del XVI, sostener la preeminencia de la épica. Y por encima de la teoría, la práctica, ya que "todo poeta que se preciara de tal nombre soñaba con componer la gran épica de su tiempo" (Cacho Casal 8).

$\mathrm{Al}$ igual que el resto de la producción épica del Siglo de Oro, los dos poemas que nos ocupan pueden ser vistos, al margen de sus extraordinarias cualidades literarias y de los sentimientos devocionales que pudieron motivar a sus autores y lectores, como piezas al servicio de una determinada legitimación de 
tipo político y social. De un lado, están insertos en la gran tradición de la épica, que presenta una perspectiva teleológica de la historia, y providencialista, en la épica moderna, con la consideración de la historia política como medio dispuesto por Dios al servicio de la bistoria salutis.

Se me permitirá un rodeo que, espero, permitirá tener a la vista la relación entre épica y política. David Quint pone de manifiesto una "cadena de imitación" de las hazañas de Aquiles narradas en la Ilíada, cadena motivada por programas políticos de ambición imperial. Así como Jerjes visitó Troya acaso considerándose vengador de la ciudad asiática caída por obra de los griegos, Alejandro honró la tumba de Aquiles, de quien se decía descendiente y cuyas hazañas (particularmente la derrota de Héctor y con ello la de todo su pueblo) adoptó como modelo para sus conquistas. Del mismo modo, Julio César tomó como modelo a Alejandro, con el mismo afán de expansión imperial, asegurando ser descendiente del troyano Eneas. Hasta aquí el segmento de una cadena imitativa que opera en el plano puramente político y militar. Pero es Virgilio quien convierte esta apropiación política de las hazañas homéricas en materia de nueva epopeya, en materia literaria que, a su vez, se pone al servicio de un programa político. La Eneida muestra, después del deambular de Eneas, que no encuentra un sitio en el que establecerse (que abarca los seis primeros libros, a los que Quint designa como su Odisea), sus hazañas en Italia (su Ilíada, que ocupa los últimos seis libros), que serán, tal como las muestra Virgilio, "the founding events of a Roman history that culminated in world empire and in the rise to power and the new principate of Julius Caesar's heir, Augustus" (Quint 7). Lucano denuncia la vinculación entre la imitación virgiliana de Homero y la cadena de imitación política; el enorme poder estético de la epopeya que se pone al servicio de ambiciones imperiales. Añade el mismo autor:

The Aeneid had, in fact, decisively transformed epic for posterity into both a genre that was committed to imitating and attempting to "overgo" its earlier versions and a genre that was overtly political: Virgil's epic is tied to a specific national history, to the idea of world domination, to a monarchical system, even to a particular dynasty. (Quint 8)

A partir de ahí los poetas épicos no imitarán tanto a Homero, quien no manifiesta una posición política reconocible, como a Virgilio cuyo héroe fue "deliberately created for political reflection" (8). Los poetas que buscan sostener la ideología triunfante lo harán siguiendo el modelo acuñado de manera defini- 
tiva por Virgilio (Quint dedica no pocas páginas también a la otra épica, la de los "perdedores", que sigue como modelo a Lucano). Por dar un solo ejemplo, en el canto 24 de la segunda parte de La Araucana Ercilla hace de la batalla de Lepanto una segunda Actium, en la que la flota de Octavio vence a la de Marco Antonio; pero Ercilla no tiene en mente la batalla misma sino su elaboración literaria en el libro octavo de la Eneida, en el que se describe el escudo "profético" fabricado por Vulcano, que Venus le entrega a Eneas. En dicha écfrasis el poeta alinea los hechos que selecciona del pasado para hacer una interpretación total y teleológica de la historia de Roma (ver Quint 21-49). Se trata del poder que se disfraza de razón y que muestra su proyecto como el $n e-$ cesario arribo de la unidad frente al "flujo [...] sin rumbo", única propuesta posible de las disolventes fuerzas opositoras, presentadas como perdedoras (41). En definitiva:

Epic takes particularly literally the axiom that history belongs to the winners. Imperial conquest of geopolitical space -the imposition of a single, identical order upon different regions and peoples- becomes a process of history making. The Aeneid appears to identify history itself with a new idea of universal world history. (30)

En la misma línea, y en un trabajo modélico dedicado a la épica hispánica, Lara Vilà recuerda que la épica reclama, en tanto "especie poética", una lectura "eminentemente política. La épica es, por encima de todo una representación y una alabanza del poder, una interpretación que se impuso a lo largo de la tradición occidental a partir de la Eneida de Virgilio, cuya influencia en la épica hispánica no se ha ponderado suficientemente" $(2001,8)$.

Elizabeth Davis, después de recordar (remitiendo al clásico trabajo de Frances Yates Astraea: The Imperial Theme in the Sixteenth Century) que a partir de Carlos v la monarquía castellana se vuelve imperial (identificada con el Sacro Imperio), y que buscó vincularse con "mitos venerables de la predestinación y plenitud imperiales, tales como la renovación y la traslación del imperio, la vuelta a la edad de oro", etc., añade: “Toda epopeya tiene este elemento en común: que parte de su ficción es una mirada hacia atrás en búsqueda de leyendas que autoricen un estado y una política presentes" (329). (Esa función tiene la mencionada écfrasis del escudo de Eneas, que por supuesto será imitada en la épica hispánica).

En el trabajo ya citado de Vega y Vilà, las autoras ponen de relieve que en el siglo XVI este fenómeno es común a todas las dinastías europeas en ejer- 
cicio, las cuales recurren para su provecho a la elaboración de genealogías fantasiosas y míticas que las harían descender de Roma y, obviamente, de Troya. Podemos añadir que algunos hábiles constructores de fraudes se pusieron al servicio de tales aspiraciones y sumaron, además, el "factor bíblico". Un caso típico es el del dominico Annio de Viterbo, quien dio a luz Antiquitatum Variarum, un fingido corpus de textos supuestamente caldeos, persas y otros

publicados a fines del siglo XV y cuyo objetivo era reivindicar el origen de los Reyes Católicos y de otras monarquías europeas [... Viterbo] construyó su historia a partir de un criterio oportunista: la vinculación entre varias tradiciones de la Antigüedad clásica y los patriarcas de la Biblia, trazando así una genealogía común. El principio de este método consistía en sostener que se trataba de los mismos personajes, pero cuyos nombres habrían variado de un lugar a otro. (Eichmann/Zuleta 29)

Con convicción (real o aparente), muchos hombres del siglo XVI asumieron como válidas tales patrañas. Así, no le tiembla la mano a Pedro Sarmiento de Gamboa cuando afirma que su familia entronca con Titeo, hijo post diluviano de Noé, el primero que plantó viñas en Galicia, por lo que sus descendientes, soberanos del país, llevaron el nombre de Sarmiento. De lo que se trataba (sobre todo para las casas reales) era de lograr, a través de medios diversos, como indican Vega y Vilà, "un repositorio de formas de representación del poder y de la continuidad dinástica, un ingrediente de legitimidad histórica y genealógica, y una singular manifestación de la memoria política y fabulosa de Europa. Entre tales formas de representación ocupa un lugar privilegiado la épica" (15). Vuelvo a remitir a ambas autoras, quienes señalan que

en el caso de Portugal y España, la percepción de la historia presente parece filtrarse por el tamiz virgiliano, y sustentarse, por tanto, sobre la convicción de que el imperium sine fine que Júpiter vaticina ante Venus para los descendientes de Eneas se cumple realmente con las navegaciones y descubrimientos que se suceden desde fines del siglo XV. (15)

En el siglo XVI y hasta entrado el XVII había un proyecto colectivo enormemente ambicioso que se concibió en orden al beneficio general, identificando este con la extensión mundial de la fe católica y la organización de la sociedad bajo la corona castellana que garantizaba la puesta en práctica de los piadosos designios de Dios. La convicción de que podía realizarse dicho proyecto fue tenida por algo evidente, y fue adoptado con compromiso también entre los 
indígenas americanos. Entre otros, son muy elocuentes los ejemplos que se hallan en la crónica de Domingo Chimalpahin en México (Gruzinski 35-38), y lo mismo podemos decir para Charcas, por ejemplo si analizamos las pinturas de la Virgen Cerro de Potosí (ver Eichmann). La literatura de la época confirma esta convicción general, como observa Raffaelle Puddu:

La participación en las empresas de una nación que llevaba las armas y la cruz a los cuatro rincones del mundo, el solo hecho de pertenecer a ella, dictaba expresiones de orgullo a todo español que empuñase la pluma, ya se tratara de Cervantes, Lope de Vega o de alguno de los tantos veteranos de Italia y Flandes que confiaban a la letra impresa el relato de sus experiencias militares. Historia y mito eran sincrónicos y, ya se afrontaran molinos de viento o se combatiese contra los rebeldes de Holanda, lo imaginario imprimía sobre lo real un sello extraordinariamente profundo. (12)

Estos son aspectos insoslayables del contexto en el que aparecen nuestros poemas. Pero hay algo más, que apunta a la legitimación no solo política sino también social que anuncié al comienzo de este acápite: existe una marcada diferencia entre la producción épica americana y la peninsular, la cual afecta a nuestros dos poemas. Son también (y junto con infinidad de otros textos, literarios o no) "un vehículo formidable para el proyecto criollo americano que reclama su incorporación en la geografía política del imperio de la casa de Austria" (Vélez Marquina 2010, 44; el autor se refiere particularmente a la obra de Oviedo y Herrera). Mazzotti advierte todo un movimiento de "criollismo militante", en respuesta al ninguneo ("falta de compensación real y simbólica”, 22) que el sujeto criollo recibía por parte de la metrópoli y de los peninsulares que llegaban en oleadas a América y que cobraban sin mérito propio los frutos del esfuerzo criollo. Tal criollismo se gestó junto a una "subjetividad colectiva que bien merecería recibir el nombre de nacionalismo étnico preilustrado, con el sentido limitado y selectivamente ancestral que el concepto de nación tenía en la época" (236).

Veamos cómo funciona en nuestros autores. Valverde se manifiesta parte, por supuesto, del gran proyecto de la instauración de un reinado universal al servicio de la salvación de los hombres por medio de la religión católica. Por esto desea que su poema se considere, precisamente (aunque no solo, como ya vimos), épico. Pero a la vez lamenta los aspectos no deseables de la realización de tal proyecto; aspectos que solamente la Providencia, por medio de la Virgen María, es capaz de rectificar, gracias a los cuidados maternales que dis- 
pensa a los indígenas. Indica que lo que obra la Virgen en Copacabana es algo épico, ya que se trata de la

fundación de un imperio nobilísimo cual es el de la fe y la gracia en estos reinos del Perú; cuya conquista temporal por los reyes católicos de España era preciso que en la divina providencia estuviese íntimamente conexa con este grande fin del provecho deste nuevo mundo, como altamente lo muestra el doctor Solórzano: ${ }^{2}$ triunfos de la idolatría tan señoreada del Perú, $y$ de los vicios con que tanto ba procurado el demonio afear lo bermoso de los fines con que nuestros gloriosísimos reyes emprendieron la conquista de las Indias. ( $\mathbb{\|} \mathbb{\mathrm { v }}$; el resaltado es mío)

Valverde establece una distancia entre su posición y la violencia de la conquista, recogiendo el acento lascasiano de rechazo a la rudeza y crueldad de Pizarro y sus compañeros. Así (tal como ya hizo notar Mazzoti), un personaje alegórico que personifica al Perú le dice a la Virgen, en la silva XVIII del poema: "sonome a esclavitud el rudo celo / de tus embajadores / en quienes vi crueldades, vi furores" (fol. 282v). Al referirse a Lima, el mismo personaje afirma que "hijos produce fértil generosos / que a sus padres retratan belicosos" (fol. $287 \mathrm{v}$ ). Pero no se desmarca solamente de la conquista, sino que también asume (como tantos otros criollos), en muchos pasajes de su poema, "la defensa de la población indígena frente a los abusos de corregidores y oficiales de la Corona" (Mazzotti 239).

Esta es la primera parte de la operación autolegitimadora criolla, la más eficaz, dado que aparenta no actuar en interés propio. La otra consiste en mostrar la valía de la propia clase. Le interesa (como a infinidad de criollos) mostrar el virreinato peruano como cuna de ingenios preclaros. En su caso el elogio va dirigido a Lima, ciudad a la que iguala con Madrid. Añade que la sede virreinal muestra "sus fulgores / en cándidos albores, / mejoro 3 de la nieve castellana / nacida en cordillera peruviana" (fol. 280v). Estos versos son señalados por Mazzotti como manifestación valverdiana de la "incuestionable calidad espiritual de los descendientes de esos mismos conquistadores, una vez mejorados por el suelo peruano" (248).

2. En nota marginal indica "Doct. Solorz. li. 2 De Indiarum iure fere per totum". En el libro indicado La expresión "fere per totum" aparece en el cap. 12, núms. 3 y 9; tal vez haya errata en los números, porque en ninguno de ambos casos vemos relación con lo que expone Valverde.

3. "mejoro": 'mejoría' o aventajamiento (CORDE recoge siete ejemplos, de fines del siglo XVI y principios del XVII, en los que se utiliza la palabra con ese sentido). 
En definitiva, Valverde, al igual que muchos criollos, asume el proyecto universal emprendido por la Corona, pero busca negociar (por medio de un poema épico de extraordinaria calidad) un mejor puesto en la estimación de quienes manejan el aparato estatal y definen el estatus social y político de los diversos sectores de la población.

Veamos ahora la obra de Oviedo. El poeta, siguiendo un camino ya trazado por sermones y piezas hagiográficas santarrosinas, manifiesta el más alto triunfo de la clase criolla, uno de cuyos integrantes, Rosa de Santa María, alcanzó la gloria de los altares con su canonización. Señala Vélez Marquina que el poema se despliega en forma de negociación de la élite criolla, al proclamar "la existencia de un nuevo centro de poder, de una nueva ciudad cristiana, cuya sociedad ha dado un notable fruto de santidad que instaura un nuevo paradigma de heroicidad" $(2010,84)$. En otro trabajo (en el que compruebo interesantes puntos de contacto con este acápite) el mismo autor observa que Oviedo y Herrera pinta una sede virreinal "que encarna los ideales de la élite criolla; a saber, una ciudad que es representada en el poema como hispánica y católica, en la que los indios-idólatras no forman parte del gobierno de la misma y los extranjeros-herejes (protestantes) son rechazados gracias al poderío religioso y militar de sus ciudadanos" (Vélez Marquina 2017, 146). Por lo dicho se observa que no se celebra un triunfo "contra" o en desmedro del centro del poder, sino que fue aprovechado como oportunidad de mostrar que era también un motivo de engrandecimiento de la metrópoli, cuya empresa evangelizadora en América demostraba haber alcanzado la más alta meta.

Pedro de la Peña (uno de los autores de preliminares que veremos en este estudio) considera que la beatificación de Rosa es, precisamente, "glorioso desempeño al motivo de la conquista de las Indias"; y añade también que es "ornamento esclarecido de las coronas de Lima su metrópoli” (e2 3r). ${ }^{4}$ Núñez de Roxas (otro de los autores de preliminares que nos interesan) celebra el hecho de que, por proceder el poeta de la Península, "corriesen sus elogios [de Rosa] sin encogimientos de interesados" (Núñez de Roxas C2 2v; lo dice porque Oviedo es peninsular). Total, todos ganaban con la santa, pero sin duda el acento está puesto en la capacidad de la criolla Rosa de aunar a todos los habitantes de América. Señala Mújica Pinilla que

4. Alusión a las coronas de los Reyes Magos, que dieron identidad a la ciudad en los primeros tiempos (era "la ciudad de los Reyes" por la proximidad de su fecha de fundación con la fiesta de la Epifanía). 
Aun en México el regocijo general por la beatificación de la primera santa americana es un "admirado concurso de nobles y plebeyos, de señores y esclavos". Así lo sostiene [...] Francisco de Burgo [...]. Todos los "hijos de la América" saben que Rosa es "una flor para adorno de nuestra tierra, no para vasallaje de su imperio sino para ilustre blasón de nuestro país, no para posesión de su corona sino para compañera y domiciliaria de nuestro destierro y valle de lágrimas" [...]. En su relación sobre las fiestas realizadas en Oaxaca por la beatificación de Rosa, Pedro de Arjona también se refiere a ella como a "nuestra paisana" que tiene "nuestra naturaleza criolla". (Mújica Pinilla 45)

Añade el mismo autor que una pintura de Lázaro Baldi en la que se la representa

protectora divina de criollos, indios, negros y mestizos [...] venerada por todos los grupos étnicos, "naciones" y "provincias circunvecinas" del Perú, por sí sola ejemplifica el valor unificador de su culto político-religioso, el cual [...] fue utilizado y significó distintas cosas para los diversos grupos sociales. (60)

En uno de los preliminares del poema de Oviedo y Herrera leemos que

el aplaudir las prodigiosas virtudes de la gloriosa virgen santa Rosa de el Perú, [...] es lo mismo que exaltar a todo aquel reino y singularmente a la ciudad de Lima, fecunda concha de esta más peregrina divina perla, según lo observaban los griegos en sus célebres certámenes, aclamando por triunfos de los lidiadores el nombre de sus patrias. (Núñez de Roxas 62 3v)

De modo que ambos poemas legitiman a la clase criolla en los paradigmas propios de la república de las letras y en la tradición peculiar de la que forman parte, la épica culta hispánica, que heredó entre otros aspectos esenciales del canon de Ferrara la "glorificación [...] de estirpe y de nación" (Prieto 143). Como ya se dijo, tanto los poemas como los preliminares citados en este acápite manifiestan el intento de los criollos de procurarse una mejor posición dentro del proyecto imperial del que, por supuesto, se sienten parte.

\section{Los preliminares: contenido general}

La revisión de los paratextos de estas obras me parece una tarea que, aunque algo morosa, permite dar cuenta de una parte de la presencia del andamiaje 
teórico que circuló durante más de siglo y medio, en ambos lados del océano. Significativamente son tres los autores de preliminares del poema de Valverde, todos residentes en Lima y todos eclesiásticos, y cuatro los de preliminares de la Vida de Santa Rosa, dos de los cuales se encuentran en la metrópoli y los otros dos en Lima. Vale la pena subrayar esta amplitud geográfica, señalando los lugares de nacimiento y de actividad que les tocaron en suerte. ${ }^{5}$ En cada caso indico el tipo y la extensión del paratexto que publica y ofrezco un esquema de lo que desarrolla.

\section{En la obra de Valverde}

Fernando de Valverde, el autor: fraile agustino nacido en Lima (reside en Lima). Prólogo (8 fols.).

Comienza narrando una experiencia personal, cercana a la mística, ocurrida en una visita a Copacabana, gracias a la cual comprendió que el objeto de los milagros obrados allí por la Virgen era fundar en el Perú un imperio de fe y de gracia. Esto le llevó a sentir el impulso de escribir el poema, de asunto heroico (la fundación de un imperio, bien que espiritual) pero cuyo espacio (la campiña cercana al lago Titicaca) y personajes eran más apropiados para la poesía pastoril. Por ello pretende haber abierto una nueva senda poética, compuesta de épico y bucólico. Acude a la autoridad de Virgilio para mostrar que en las églogas también se pueden cantar "cosas mayores que las rústicas". A continuación explica que no cantará a las excelencias de la Virgen, sino (siguiendo la doctrina aristotélica de Poet, 1451a 16-29) una sola acción suya, la fundación del mencionado imperio espiritual; a lo que se añade la acción subordinada del místico pastor, Graciano, y sus interlocutores. Seguidamente expone autoridades del mundo clásico, de la Biblia y de autores medievales y modernos para justificar la introducción de la Virgen como pastora, con el nombre de Amarili. Después de ponderar la sublimidad de la poesía, señala algunos de los requisitos aristotélicos para la épica, por ejemplo que esta no debe referir cosas sucedidas (acude a Aristóteles, Poet, 1451 in fine-1451b, 15) sino que transmite una materia fingida y verosímil, que imita las acciones humanas o divinas; a lo que hay que añadir "alteza de conceptos y sentimientos escondidos" y "elegancia y hermosura de locuciones y dialectos", todo lo

5. Dejo de lado los autores de aprobaciones y otros preliminares que no se pronuncian sobre cuestiones relativas a la poesía. 
cual se verificaría en su poema. Indica que en la Ilíada Homero quiso mostrar unas acciones y personajes, en el plano de la ficción, que no eran sino alegorías de lo divino y lo humano. Recuerda que Horacio (se refiere a Arte poética, vv. 333-46) mostró que es propio del poeta "aprovechar deleitando", e identifica el primero de ambos elementos con la filosofía moral. Por supuesto, ello ocurre sobradamente en el poema salido de sus manos, cuya finalidad es que los lectores se vean penetrados de veneración a María, de confianza y de ternura, que broten en ellos el aborrecimiento de las culpas (al ver las de sus personajes Adamio y Megerino) y que sigan el ejemplo del místico Graciano. Acaba el prólogo recurriendo a multitud de autoridades para mostrar que su ocupación de poeta no está reñida con la gravedad de su oficio.

Juan de Ribera: fraile agustino, catedrático de la universidad de san Marcos (reside en Lima). Aprobación (1 fol.).

Cuenta que con la lectura del poema le ocurrió lo que a Gregorio Nacianceno cuando leyó el Hexameron de san Basilio, que sintió a Dios más al alcance de las manos. Después de varios elogios a la obra y a la devoción manifiesta de su autor, expresa que, según cree, los entendidos que suelen desganarse ante libros puramente devotos se sentirán atraídos por este, que transmite contenidos elevados pero "con lo apacible de las Musas". Cierra su breve texto con un par de elogios más, para lo que acude a citas de Quintiliano, Plinio y una carta de Símaco a Ausonio.

Pedro de Ortega Sotomayor: es arcediano en Lima y catedrático en la Universidad de san Marcos (reside en Lima). Licencia (1/2 fol.).

Afirma que el poema es un gran incentivo de la devoción, y pondera el deleite que proporciona "al son de los instrumentos y voces de las musas".

\section{En la obra de Oviedo y Herrera}

Oviedo y Herrera, el autor: corregidor de Potosí de 1667 a 1671 y de 1674 a 1680; Consejero del virrey duque de la Palata y corregidor de Huánuco entre 1701 y 1705 (reside en Lima). Dedicatoria “A la reina de los ángeles María Santísima" (2 fols.).

Se declara incapaz de copiar la excelencia de Rosa, cometido tan imposible como describir con tinta los rayos del sol sin que los rasgos parezcan borrones. Asegura que para escribir el poema fue arrebatado por la devoción más 
que por el furor poético, y que esta lo embarcó en empeño imposible, dado que Rosa supera cuanto pueda concebirse en este mundo. Manifiesta su confianza en que el nombre de Rosa, puesto "en la frente" de su obra, le dará más valor, como ocurre con las monedas, que llevan inscrito el nombre del soberano. Termina diciendo que si las hojas del poema que le dedica (a la Virgen) estuvieran marchitas por el contacto con su mano tendrán, "por mortificadas", un parecido mayor con Rosa.

Juan de las Evas: teólogo, predicador de su Majestad (reside en Madrid). Aprobación (4 fols.).

Según afirma, ninguna obra le produjo mayor admiración. En ella ve restituido el "sacro furor" poético, en que se reúnen elegancia y facilidad con que cumple el doble propósito horaciano. San Ambrosio creyó ver en Moisés la misma intención, cuando cifró en agradables cantos la liberación de los hebreos. Tal fue el estilo de los profetas y, por supuesto, de algunos padres de la Iglesia. El canto halaga el gusto, mientras que el contenido enseña. A continuación asegura que el autor descubrió la mina más rica de América, Rosa, con cuyas vetas de virtudes tejió "sonoras enseñanzas" fruto de su ingenio; estas son tanto más valiosas que las de Potosí cuanto lo fueron las riquezas intelectuales de Salomón en relación con las naves de Tarsis. Considera que después de la muerte de Rosa, sus virtudes habían quedado deslucidas en las biografías (por estar en prosa, se entiende), mientras que ahora gracias a la poesía reciben nueva alma, vida y ardor. Repite lo de Ambrosio, al que añade ahora el ejemplo de Alejandro Magno, para quien la poesía homérica era acicate para las mayores hazañas. Las penitencias de Rosa, que pueden asustar a los tibios, dice, son tan agradablemente leídas en el poema que pueden encender los corazones. A continuación expresa su asombro por el hecho de que Oviedo y Herrera, llegado al Perú a modo de "descanso de sus militares fatigas", en lugar de pensar en enriquecerse se haya dedicado a meditar en la penitente vida de Rosa y a pintarla para provecho de otros. Continúa con el motivo de la nobleza, que en Oviedo se nota por sus obras más que por sus muy ilustres antepasados; lo que se verifica también porque empleó sus pocos espacios libres en esta obra (aquí añade que también las diversiones de los nobles deberían ser provechosas para la república, idea que refuerza con una cita de Sidonio Apolinar). Da su voto a favor de la publicación del poema, y homenajea al autor con tres octavas reales en las que vuelve sobre algunos de los conceptos arriba expuestos. 
Miguel Núñez de Roxas: limeño, doctor en ambos derechos por la universidad de San Marcos de Lima, del consejo de su Majestad (reside en Madrid). Censura (8 fols.).

Comienza diciendo que comenzó a leer la obra por obligación (se le encargó la censura), pero que la leyó lleno de gusto y satisfacción. No cree estar a suficiente altura para elogiarla, si bien se siente a ello obligado por el asunto del poema, que es aplaudir las virtudes de Rosa, que es lo mismo que exaltar a todo el Perú, y particularmente a Lima. Fuera de ello, aunque se siente indigno hijo de Lima, "dichosa madre de la santa", debe honrar los vínculos de su familia con la ciudad, por haber su padre recibido de ella (como oidor decano de su audiencia) el nombramiento de patrono del monasterio de Rosa de Santa María, inaugurado en 1708; y también por contarse otras familiares suyas (una tía y dos de sus hermanas) entre las fundadoras.

El poema acredita al autor "por el más legítimo hijo de las musas"; las academias supieron aplaudir a "su esforzado Apolo" tanto como las campañas de Flandes publicaron su "discreto Marte". Sazona lo dicho con una referencia a Arquíloco y una cita de Alfonso de Palencia.

El que Oviedo y Herrera dejase la corte de Madrid, donde tenía abiertas grandes posibilidades granjeadas por su pluma y su espada, para ir al Perú, solo puede explicarse por "soberano impulso" del cielo. No fue para que llegase su nombre al hemisferio Sur, porque ya había llegado; ni para que enriqueciera la lengua castellana en el Perú, pues esta ya era tratada con perfecta destreza, sino porque Rosa lo trajo para que se hiciese cargo de un panegírico a todas luces desinteresado, por no ser él paisano de la santa.

Compara las biografías de santa Rosa, escritas en una prosa de estilo poco moderno, con los logros extraordinarios del poema de Oviedo y Herrera. Pondera también el que su autor no se aparte de "la obligación de historiador ni de los preceptos de poeta", ya que supo combinar sin confundir historia y ficción. Con la ficción hermosea la verdad "por no faltar a este tan preciso documento del Parnaso", como (según dice) le ocurrió a Lucano.

Añade (con profusión de citas y con recurso a la imagen de la abeja, de Isócrates) que los lectores podrán deleitarse sin temor a encontrar nada amargo, ya que todo es bueno en el pensil de Oviedo. Acaso por eso esperó, copiando al cisne, a su "cana edad" para escribir sobre "tan elevado y devoto asunto" (esto lo dice de la mano de Pierio Valeriano). Habiendo ardido sin consumirse su devoto numen, merece fama inmortal; y así como en Roma las losas que llevaban nombres de poetas romanos eran cubiertas de 
rosas, que evocan a la "lasciva madre del profano amor", sobre el nombre de este poeta corresponde esta otra Rosa sagrada y casta. Sigue una complicada operación por la que muestra que Oviedo supera una propuesta de Francisco Mendoza (en su Viridarium, de 1635), de preferir la belleza de la rosa a la de la luna. Santa Rosa es hija de mejor jardín que el de Mendoza, por ser el de Lima, ciudad de la que misteriosamente habrían hablado las divinas letras (?).

Manifiesta su parecer de que se le dé no solo licencia para publicar el poema, sino que se empeñe al autor a hacer lo propio con otros "partos de su fecundo numen". Sigue una nueva hipérbole referida al valor de armas y letras de Oviedo, con una cita de Arquíloco (tomada de Tácito). Acaba aplicando al poeta unos versos de las Pónticas de Ovidio.

Total, es la pieza más larga de los preliminares, llenos sus márgenes con 35 notas marginales de eruditas citas y referencias.

Pedro de la Peña: racionero de la catedral limense, catedrático en San Marcos, consultor del Santo Oficio (reside en Lima). Parecer (6 fols.).

Después de largos cumplidos iniciales, recuerda las fatigas y riesgos asumidos por Oviedo y Herrera en Flandes, hasta la Paz de los Pirineos, gracias a la cual pudo cambiar de ocupación, trasladándose a Madrid para (entre otras cosas) participar en la proclamación de Carlos II, y pasando más tarde al Perú. Recuerda que cuando Oviedo ocupaba el cargo de corregidor de Potosí llegó la noticia de la beatificación de santa Rosa, de cuya celebración se ocupó personalmente en la Villa Imperial. Pero no quedó contento con solos los "obsequios transitorios" y decidió dedicar a Rosa, con su esfuerzo, otros que fueran durables. Manifiesta que la obra merece ser publicada, porque en ella el autor alcanzó, mejor que ningún otro, la mayor cumbre de la poesía, que consiste en la armonía horaciana ya vista, "con lo dulce lo provechoso".

Recuerda que los primeros poetas tuvieron el mérito de sacar a los hombres de la barbarie y llevarlos a la vida "concertada", para lo cual se valieron del ritmo ("los números") y de la fábula, "por cuyo medio engañaban con la misma verdad", con el fin de aficionar a la virtud. A diferencia de ellos, Oviedo y Herrera propone la verdad "en su traje natural", ya que se trata de las virtudes de Rosa, que están sobre toda ponderación. Aunque también, secundariamente, entretejió el poema con algo de fábula, no para mentir sino para adornar, "con moderación y provecho". Y en lo principal del poema, la elección del sujeto le confiere una indudable ventaja. 
La principal enseñanza del poema consiste en persuadir a que se siga el ejemplo de Rosa, en concreto, todas las virtudes en una, que es la caridad. De paso, señala que esta fue "la acción más continuada de la santa", y a raíz de ello se pregunta si Oviedo optó por ello precisado por el precepto (aristotélico) de la épica, o si a la elección de asunto precedió la del sujeto. Deja abierta la respuesta, y vuelve sobre la caridad como el más aventajado asunto: otros poetas ponderaron una sola virtud en el personaje cuya acción narraron en sus poemas, mientras que Oviedo y Herrera cantó la que las cifra a todas en el "más soberano ejemplar de los siglos y la más prodigiosa heroína que celebra la Fama". El cielo dispuso, en el nombre mismo de la santa, la mencionada virtud, por ser la rosa su símbolo, afirmación que apoya con un pasaje de Vitis mystica de san Bernardo. También llamó la atención de Oviedo y Herrera, dice, la "simpatía" de la rosa con las musas; esto lo adereza con unos versos de Anacreonte vertidos al latín. Continúa con el acierto del poeta, al haberse ocupado de la caridad, compendio de virtudes, y añade una observación de interés para nosotros: no falta en el poema el amor profano, con que cumple una ley que sostienen muchos críticos; pero aquí el artificio de Oviedo consistió en mostrar a Venus vencida, "sin que se oiga algún triunfo a favor suyo".

De la Peña admira el que Oviedo suavice lo útil con lo dulce en un campo dificultoso como es el de la épica, es decir "la suprema especie" de la poesía (ya no sorprende que en esto contradiga a Aristóteles, como ya vimos), de las tres que él enumera (coincidiendo con muchos teóricos desde la primera mitad del siglo XVI; ver García Berrio 102-03): la épica, la escénica y la lírica. Los poemas breves son como joyas pequeñas (anillos), mientras que el épico es una gran cadena "y así, para mantenerla con indeficiente espíritu se requieren facultades giganteas: es la más cortesana, tanto por la materia, que debe ser heroica, cuanto por el verso, que ha de ser más sonoro". Está bajo la tutela de la reina de las musas, Calíope, "que beatifica a los sujetos en el cielo de la Fama", y por eso ha de tratar cosas divinas; aduce un pasaje del Ion que también Valverde citó en su prólogo: "el poeta es una materia ligera, alada, sagrada. No es capaz de crear antes de estar poseído por un dios" (Ion 534b). Pasa enseguida a recordar que, según Aristóteles (Poet, 1447a), el mayor deleite está en la imitación apropiada de lo natural, y que esta es el alma de la hermosura de la obra de Oviedo y Herrera. Pondera su maestría en pintar y narrar episodios de Rosa; en la descripción de Lima, de Quito, del volcán Pinchinche y sitios del Perú; en la narración de las acciones bélicas y, sobre todo, en mostrar al vivo las virtudes y penitencias de la santa (se detiene con algunos jue- 
gos de ingenio), al punto de que "se mira con agrado el original en el retrato". Seguramente Rosa desde el cielo gobernó, como estrella, la mano de Oviedo, para que la retratada y el retrato fueran similares en color, luz y fragancia, tal como encuentra Ausonio (de quien cita dos dísticos) entre la rosa y Venus. Acaba dando su parecer, por supuesto favorable a la publicación.

Fernando Carrillo de Córdova: vecino de Lima, ciudad de la que fue más tarde alcalde ordinario (1726-1746); es autor de otras piezas literarias (reside en Lima). Fuicio del poema (6 fols.).

Comienza afirmando que son pocos los que a lo largo de los siglos han creado un poema heroico, y aun estos en su mayoría no han conseguido salir ilesos de las críticas. Son cuatro los que han obtenido "cátedra de prima" en este parnaso: Homero, Virgilio, Tasso y Camoens. A su vez, Virgilio habría indicado como herederos de la sabiduría a otros cuatro: Platón, Aristóteles, Zenón y Epicuro; pero este elogio volvió a los poetas, ya que Platón afirma que los primeros padres y guías de los filósofos fueron los poetas (introduce Carrillo una de las opiniones vertidas en el Lisis, siguiendo de cerca la versión latina de Ficino). A continuación, pondera lo arduo que ha de ser alcanzar tal honor si se tienen en cuenta las cinco cualidades que, según Platón y Aristóteles, son necesarias para componer una epopeya; cualidades necesarias para algún aspecto de la creación y asociables a los sentidos, según la siguiente distribución:

\begin{tabular}{c|c|c}
\hline Cualidad & FInALIDAD & SENTIDo \\
\hline ingenio & semilla & vista \\
\hline juicio & organización & olfato \\
\hline imitación & alma & gusto \\
\hline estudio & alimento & tacto \\
\hline estilo & hermosura & oído \\
\hline
\end{tabular}

(No corresponde ahora adentrarse en el alcance de cada cualidad y sus relaciones con los demás elementos del cuadro). Concluye que rara vez la naturaleza acumula todos estos talentos en un solo sujeto, y que solo merece el nombre de poeta aquel afortunado que los posee. $\mathrm{Y}$ añade que querría tener la capacidad de Quintilio Varo (crítico elogiado por Horacio) para hacer el examen del poema de Oviedo y Herrera. Si bien la modestia de este último le lle- 
va a esconderse de la luz pública, corriendo una "cortina de grana" sobre sus obras, los amigos le instaban para que "dejase amanecer con vida de astros inmortales unas rosas tan dignas de la eterna luz". Pero ni el examen de varones doctos ni el "asedio de valientes razones" ablandaron su "constante modestia", hasta que finalmente fue la piedad del "soberano Asumpto" la que lo convenció para que compusiera el poema. Entonces, Oviedo y Herrera, como Jericó ("república de rosas"), abandonó toda resistencia y en muy breve tiempo escribió la epopeya, a pesar de achaques y ocupaciones.

En el asunto, en la invención y en la distribución de las partes se advierte "la observancia de las estrechísimas leyes de la épica". Pasa revista primero al asunto, diciendo que Platón, Plutarco y Tasso (entre otros) no excluyen a la mujer del ejercicio de la virtud heroica, y ningún sujeto puede escogerse más alto que santa Rosa, victoriosa en la "civil interna guerra de las humanas pasiones". Este "divino triunfo", narrado débilmente por historiadores (biógrafos), reclamaba el vuelo sublime de la pluma poética del autor. Con este pago, "en moneda de oro" queda compensado el rezago de la recompensa a tanto "mérito infeliz de la nobleza de este reino", que quedó "en las cerradas arcas del silencio".

Sigue con la invención, cuya perfección consiste en imitar, que es el alma de la poesía. El autor muestra el poder de la gracia divina en un alma esforzada, frente a la oposición del demonio. Ello con toda verosimilitud (los colores de la poesía no impiden ver la verdad desnuda) y sin recurrir a alegorías amatorias que ya Virgilio supo evitar, a la vista de las críticas de Sócrates. Considera Carrillo que la poética cristiana no sufre "las fabulosas licencias de la gentil”, que sí necesitaba de la fábula, aunque alegórica. Al suponer en sus personajes una virtud sobrehumana, para guardar la verosimilitud debía recurrir a una fingida "especial asistencia de los dioses". Pero el poeta cristiano, al tratar de una persona santa no necesita tal cosa, ya que le bastará contemplar en su vida prodigiosa las "celestiales apariciones y portentosos milagros". Bien es cierto que se considera esencial a un poema heroico la fábula, para deleite del ánimo y captar la atención con la imitación artística de la naturaleza. Pero cuando la naturaleza ofrece algo ya perfecto, el arte ya no tiene cómo copiar tal rareza; y si a tal cosa se atreve ha de recurrir a la misma naturaleza para proveerse de los materiales. Pasa después a considerar los poemas en los que la fábula abarca toda su extensión, y opina que ponen como velos "al nativo esplendor de la verdad", defecto que le valió a Homero la reprehensión de "impío" por parte de Sócrates y Platón. Sería un evidente error imitar a Homero solo en lo que erró. Virgilio, escarmentado, “entretejió oportunamente 
la fábula en la serie de la obra”, y lo propio hizo Oviedo y Herrera en su poema, en cuyo canto VI aparecen Yupangui y Vilcaoma, y "los concilios de Lucifer contra la santa". Por lo demás, contra lo que afirma Manuel de Faria i Souza en sus comentarios a Camoens (recordemos que eso lo afirma Valverde en el prólogo a su poema), sostiene que no todo lo que canta Homero ha de atribuirse a alegoría, pues en ese caso ningún gentil habría creído lo que la mitología decía de sus dioses. Acaba esta parte mostrando que Camoens introdujo a Venus como tutelar de los portugueses por imitar a Virgilio "que la finge patrona de los troyanos".

Sigue con la distribución de las partes, y afirma que en ello el autor siguió, "arrebatado del impulso de Febo, los cuatro movimientos que le atribuyen los astrólogos", es decir el annuo (en la "nerviosa conexión de los episodios"), el mestruo (en lo agradable; por supuesto, con frutos de doctrina), el diurno (en la "numérica proporción") y el nocturno (lo declara presente en el tallado resplandeciente de cada verso). Total, que cumple los requisitos de (el abate Secondo) "Lanceloto" para un poema moderno: "nervio, hermosura, número y candor" (Lancelotto 215).

Según Ficino, los platónicos creyeron que en las ocho esferas había sendas musas, cuya armonía atribuían a Calíope. Esto se confirma en cada octava del poema, que desprende celestial armonía. Continúa Carrillo el juego con la armonía de la octava musical.

También cumplió Oviedo con las reglas del arte: en la elección del asunto, que no es ni muy remoto (en lo que erró Virgilio) ni demasiado moderno; en la materia heroica ("en que pecó Ariosto"); en la heroína, que es solo una (en lo que "faltaron Tasso y Homero"); en la invención ("que no tuvo Lucano"); "en el estilo sublime y claro, que no concilió Papinio" (es decir, Estacio, en su Tebaida); y en la propiedad de los estilos según los sujetos (el decoro), "que tanto desea Horacio". Carrillo desiste de enumerar las demás perfecciones del poema, y sobre todo de referirlas a reglas. Considera que en poesía "no hay discípulos" que puedan aprender, porque "todos los de este arte son maestros"; los verdaderos poetas viven con las leyes como los príncipes, sin sujetarse a ellas como los vasallos.

Por último, dice que si Platón considera necesaria la misma fuerza divina para interpretar y entender un poema que para componerlo, Carrillo por su parte no podrá manifestar las perfecciones de esta obra, por lo que anima al lector a navegar en el poema sin perder el rumbo, mirando bien al sol como diestro piloto. 
El resumen que se ha hecho de lo que exponen estos autores de preliminares permite, ante todo, notar que se prestan a multitud de estudios, dado que tocan numerosos tópicos de la teoría literaria renacentista y barroca. Es imposible en la extensión de este trabajo atender a todo lo que proponen. Por otra parte, nos han permitido situar la posición de unos y otros en relación con los tópicos que examinaremos ahora. Como se verá, ninguno se muestra original (las discusiones sobre la épica no eran algo reciente, y para cada afirmación puede establecerse un "árbol genealógico"), pero no es eso lo que interesa aquí. Vale la pena revisarlas porque permiten ver el tratamiento (no exento algunas veces de contradicciones) de que son objeto, lo que permite hacer una suerte de "estado de la cuestión" en el momento de la enunciación. Por otra parte permiten hacer una observación general: a ambos lados del océano circulan las mismas ideas, al punto de que no es razonable hablar de espacios distintos. Esto puede parecer una verdad de Pero Grullo, por supuesto, pero a veces incluso estas se pierden de vista y vale la pena traerlas a la memoria.

\section{TÓPICOS Y PRECEPTOS}

\section{El furor poético}

En su prólogo Valverde afirma que tras el arrebato de devoción que experimentó en Copacabana, "comencé a sentir en mí espíritu y aliento de poeta, y a experimentar lo que del Amor dijo Platón: que era Dios poeta y que sabía hacer poetas". Cuando regresó a Lima, afirma que "no pudiendo negarme a los impulsos interiores que me obligaron a labrar este poema (que arrebatándome la pluma de estudios más fundados y severos, [...] me compelían a divertirme en Pindo tan sagrado) determiné seguir los pasos de la Virgen [...] y aventurarme a salir en el teatro del mundo" con la creación de su poema (Val-

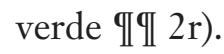

No es el único pasaje en que Valverde se refiere al furor poético. Más adelante insiste en que fueron "los impulsos interiores" los que le "obligaron a labrar este poema (cosa que nunca antes desta acción imaginé ni ejercité desde mis rudos años, pudiendo contar deste poético silencio no interrumpido más de dieciséis" (Valverde $\mathbb{I} \mathbb{1} 13,1 \mathrm{v}$ ). Y todavía: "Si hubiese a quien esta obra parezca ocupación menos conforme a las de mi retiro, lo primero responderé que obedecí [...] a los impulsos, si dulces, eficaces, con que la reina de los ángeles gustó ocuparme en estos elogios” (Valverde $\mathbb{I} \mathbb{I}[3,1 \mathrm{v}$ ). 
García Berrio (256-76) muestra todas las dificultades que tuvieron que remontar los "partidarios del furor" o entusiasmo poético para defenderlo de la burla que hace Horacio (Arte poética, vv. 291-308) de los furiosos e intonsos poetas. Para llegar a convertirlo "en un tópico determinante de la tradición poética del Occidente europeo a partir de la segunda mitad del siglo XVI" (266), buscaron diferentes maneras de restablecer la idea platónica de inspiración, purificándola del mito pagano. Julia Sabena, por su parte, señala con acierto que, ya en el siglo XVII, el furor es adoptado sin reservas por Góngora y los poetas gongorinos. Del binomio ars-ingenium, en el Renacimiento tuvo mayor peso el primero de los dos términos; el segundo pasó a la delantera en el "barroco más acendrado" (Sabena 2014, 118). ${ }^{6}$

El camino que recorrió el furor hasta su triunfo en las teorías poéticas tuvo entre sus campeones españoles a Luis Alfonso de Carvallo, que le prestó atención extensamente, de la mano de neoplatónicos italianos como Policiano, Vida, Pico y, sobre todo (aunque no lo menciona), Marsilio Ficino (Nallim 76). ${ }^{7}$ Todos desarrollan sus teorías a partir del Ion y del Fedro, donde Platón

afirma que hay dos especies de locura, una humana y otra divina y, a su vez, en la divina distingue cuatro clases que adscribe a cuatro dioses: a) la profética o adivinadora, a Apolo, b) la de los iniciados en los misterios, a Baco, c) la poética a las Musas, d) la amorosa, a Afrodita y Eros. Sabemos también que proclama la supremacía a esta última. (Nallim 75)

Ficino observa que el orden que acaba de exponerse, del Fedro, es distinto en el Banquete, donde el orden es: a) poético, b) místico, c) profético y d) amoroso). Y explica que Platón lo altera porque en el Fedro le interesaba explicar el origen del amor mientras que en el Banquete lo que le preocupaba era "el retorno del alma" (Nallim 78). Por ello aparece en primer lugar el furor poético, como primer paso en la escala ascendente. En cualquier caso, el furor amoroso está siempre en la cúspide. En cambio, Carvallo

6. La autora hace en otro trabajo una muy útil revisión de influencias gongorinas en el poema de Valverde. Influencias que se complementan con las provenientes de otras lecturas, entre las que incluye la de Salcedo Coronel, de cuyas manos salió, dos años antes de que Valverde escribiera su poema, la primera edición comentada de las Soledades (Sabena 2016, 72-75).

7. García Berrio apunta que entre los platónicos renacentistas "el tópico del furor [...] constituía con el de la licitud o inmoralidad de la poesía las dos columnas básicas de la doctrina platónica del arte, de muy amplia difusión en Italia; aunque [...] no llegase nunca a constituir un bloque doctrinal de consistencia y unidad equivalente al horaciano o al aristotélico" (265). 
olvidó o no vio bien que [...] la ordenación de distintos tipos de inspiración está supeditada a otros intereses: el retorno del alma, el origen del amor. De ahí que cuando Carvallo adopta los mismos cuatro peldaños de la escala, le resulta muy difícil explicarlos. Su interés difiere del de su maestro o sus maestros platónicos. Solo quiere hablar del entusiasmo poético y, sin embargo, seducido por el ordenamiento platónico de los furores, quiere aplicarlos en todos sus tipos para exaltar el oficio del poeta. [...] La materia que en Platón o en Ficino puede tener un valor porque es parte orgánica de una doctrina más extensa pierde ese valor total o parcialmente cuando es escindida del todo original. (Nallim 79)

Por su parte, Valverde, que parece seguir (no solamente en esto) a Carvallo, da la impresión de tener en mente tanto el furor poético, por el cual el poeta, "como fuera de sí, viene a trazar y componer tanta variedad no solo de versos y coplas, pero de mil invenciones altas y subidas" (Carvallo, fol. 207v), como el "furor de religión", el mismo que arrebató a David y lo llevó a bailar ante el arca del Testamento "por donde le vino su mujer a motejar de loco" (208r). Remata Carvallo su exposición sobre este tipo de furor con un poemita del que cito algunos versos: "Furor de religión es el segundo / que el espíritu inflamado de tal suerte / que olvidado de todo lo que es mundo / a venerar a Dios tan solo advierte / con un fervor fogoso y furibundo".

Tres de los preliminares del poema de Oviedo y Herrera abordan este tópico. Primero el propio Oviedo; en la dedicatoria que titula "A la reina de los ángeles María santísima” afirma que escribió "arrebatado aun más que de el furor poético, del dulce imán de mi fervor devoto" ( $a 21 \mathrm{v})$. Se encuentra en el terreno del furor amoroso, por el cual, en palabras de Carvallo, "inflamado el poeta con tanto calor viene a tener muy fuerte la imaginativa, la cual por serlo tanto recibe en sí las especies de la cosa hermosa, con grande aprehensión y conocimiento" (204v), y también, por devoto, en el del furor religioso.

Juan de la Evas dice que de todas las obras que de ingenios varios leyó su curiosidad, "ninguna me ha llevado más la admiración, pues veo restituido aquel antiguo sacro furor de los poetas más grandes, excediendo a muchos e igualando a todos" (a 3 r). Lo escueto del pasaje hace imposible llegar a mayores precisiones.

Fernando Carrillo de Córdova, después de ponderar diversos méritos del poema, dice que no desea incurrir en demasiada prolijidad exponiendo todas sus perfecciones. Y cierra el párrafo con lo que sigue: 
intentar reducir a número las reglas que dan a su arbitrio los autores es querer, otro que el mismo Apolo, arrendar las pías de su tiro; porque tengo por cierto que más leyes guarda el legítimo poeta por la inspiración del numen que le inflama que por los preceptos de Aristóteles y Horacio. Y así creo que por el arte poética no hay discípulos que aprehendan; todos los de este arte son maestros que enseñan. Los mismos números que escriben son las leyes que obedecen [...]. No es imperio de elección, sino de sucesión, a que solo son llamados aquellos planetas de magnitud primera, en quienes imprime el sol más parecida su clara imagen. (b2 1v)

Otra vez se vuelve difícil el intento de descubrir matices en el uso del tópico, pero es indudable que en su perspectiva el triunfo del ingenium sobre el ars es completo; Platón y Demócrito han vencido a Aristóteles y Horacio.

\section{Deleite y utilidad}

Todos los autores de preliminares están de acuerdo en que lo agradable viene dado por la creación poética, compuesta de versos, en contraposición con la prosa, incluso si esta es de extremada calidad; y la utilidad le viene dada por el servicio que presta a la verdad. Quizá el lugar común más recurrente en preliminares de obras épicas, ya desde el siglo XVI,

es el que quiere que la épica sea una versión mejorada y exaltada de la historia, más memorable y enfática. $\mathrm{Y}$, sobre todo, el que quiere que la épica sea el instrumento para edificar la memoria política de las naciones presentes y para apuntalar desde la historia poética la legitimidad de una empresa política y religiosa que se representa como colectiva. (Vega 105-06)

En su "Aprobación” a la obra de Valverde, fray Juan de Ribera ingresa a este tópico con las siguientes palabras:

Paréceme que han de picar en este anzuelo cuantos por preciarse de entendidos se desganan de los libros puramente devotos, y que entra aquí lo que pasó a san Agustín con san Ambrosio: et dum aperirem cor ad accipiendum, quam disserte diceret pariter intrabat et quam uere diceret (Aug., Conf., 5, 14, 24). ${ }^{8}$ (II r-v)

8. Traducción mía: “cuando abría mi corazón para escuchar, dejaba entrar tanto lo elegante de lo que hablaba como lo verdadero que decía". 
Los libros "puramente devotos", a su entender, serían poco atractivos por ser solo (o principalmente) útiles, mientras que la obra de Valverde "hermana lo serio de la cátedra y severo del púlpito [...] con lo apacible de las musas" (Ribera II v).

A lo mismo apunta Pedro de Ortega de Sotomayor (le debemos el texto más breve de los aquí convocados: poco más de media página), quien en su "Aprobación" califica el poema de Valverde de "una amenidad suavísima cristiana en que deleitosamente, al son de los instrumentos y voces de las musas, se beben doctrinas utilísimas que van obrando después en las entrañas y abrasándolas en la devoción de la Virgen Señora nuestra y en amor de su gloriosísimo hijo" (II 3 1r). Es decir, contiene lo agradable y lo provechoso. El efecto útil que produce la poesía de Valverde es el encendimiento del alma en la devoción a María. Se ajusta a la exigencia de Tasso, para quien un poema épico cristiano debe elevar.

Los paratextos de la Vida de Santa Rosa también acuden al tópico. Juan de las Evas afirma que "juntas la elegancia y la facilidad hacen el agradable maridaje que deseó Horacio de lo útil y lo dulce, para enseñar divirtiendo o divertir enseñando" ( $a 23 \mathrm{r}$ ). Afirma que "las penitencias de la santa, que dan a los tibios susto, se ven en la destreza del autor tan agradablemente delineadas que dejan mayor sed después de leídas" ( $b$ 1v). También para este autor el deleite proviene de su condición de poema, en contraste con la prosa cuya única función posible es la utilidad.

Por su parte, Núñez de Roxas dice que la vida de la santa se hallaba ya escrita, pero "en prosa, no diré diminuta ni calificaré su estilo por poco aseado" (c2 3r); y muestra el contraste con el poema, gracias al cual la vida de Rosa adquiere "lo expresivo y conceptuoso, lo ameno y bien significado, corriendo la pluma tan libre por entre la ajustada prensa del verso, como pudiera apenas otro por entre la licenciosa libertad de la prosa" $(c 21 \mathrm{v})$.

Pedro de la Peña desarrolla a lo largo de casi todo su texto el acierto con que Oviedo y Herrera consiguió cumplir con esta doble finalidad en su poema. Afirma que "si el ápice sumo de la poesía, a que pocos aciertan, ha consistido siempre en saber conformar con dulce lo provechoso, ninguno hasta ahora se ha colocado en lo arduo de esta cumbre con mayor vencimiento que vuestra señoría" (e2 3r-v). Se extiende en la utilidad del poema (que consiste en animar al lector a seguir el ejemplo de caridad de la santa) y considera que el mayor deleite está en la aristotélica imitación de lo natural, que en el caso que le ocupa es principalmente el cautivante retrato de santa Rosa. 
En suma, el deleite viene en casi todos los autores asociado a la poesía, y la utilidad consiste en el conocimiento que provee (las verdades históricas narradas) y en el consecuente aumento de fervor de devoción mariana en el caso del poema valverdiano, o bien en el estímulo hacia la virtud para el lector del poema santarrosino. No parece encontrarse aquí nada verdaderamente novedoso.

\section{La relación entre poesía e historia}

La discusión sobre verdad histórica y verdad poética comienza a registrarse, como todos sabemos, en la Poética de Aristóteles.

El historiador y el poeta no se diferencian por decir las cosas en verso o en prosa (pues sería posible versificar las obras de Heródoto [...]); la diferencia está en que uno dice lo que ha sucedido, y el otro lo que podría suceder. Por eso también la poesía es más filosófica y elevada que la historia; pues la poesía dice más bien lo general, y la historia, lo particular. Es general a qué tipo de hombres les ocurre decir o hacer tales o cuales cosas verosímil o necesariamente, que es a lo que tiende la poesía; y particular, qué hizo o qué le sucedió a Alcibíades. (1451b 1-10)

Los tratadistas italianos del Renacimiento, neoaristotélicos, consideraron en un plano de inferioridad la Historia, y concedieron mayor "puntaje" a Virgilio que a Lucano, por poetizar este último hechos históricos.

Menéndez Pidal consideró que la épica hispánica se dividía en dos "escuelas", que denominó respectivamente "verista", que no tenía reparos en tratar sobre hechos reales, y "verosimilista", apegada al aristotelismo (AvalleArce 19-22).

Los poemas veristas constituyen el tronco de la épica renacentista española, mientras que los verosimilistas son sus ramas, mecidas por brisas de la doctrina aristotélica de origen italiano, tales como Bernardo de Balbuena en su Bernardo, o Lope de Vega en su ferusalén conquistada y, desde luego, toda la obra teórica de Alonso López Pinciano. (Avalle-Arce 22)

Otro detalle de la misma discusión consistía en preguntarse cuál había de ser la distancia temporal de los hechos sobre los que tratará el poema épico. La preceptiva consideraba que lo adecuado era que la historia que inspira al poema épico no "sea moderna ni antigua" (López Pinciano 469), lo cual también bajaba el puntaje a Lucano. El ejemplo perfecto era la Gerusalemme liberata de Tasso, cuya acción ocurre alrededor del año 1100. 
Ninguna de ambas exigencias hizo mella en poetas españoles ni americanos (con las excepciones obvias). Avalle-Arce, centrado en la épica americana, piensa que los autores de este lado del océano no tenían ninguna posibilidad de poetizar acontecimientos lejanos en el tiempo (14). Sin embargo, esto no parece argumento de peso, porque nada les impedía tratar sobre hechos de cuatro o cinco siglos de antigüedad (no era obligatorio tratar asuntos americanos), como Tasso.

El problema es resuelto por María José Vega, quien descubre las verdaderas claves generales de la épica hispánica, sin necesidad de hacer distinciones artificiales entre poetas americanos y peninsulares. En concreto, descubre en los prólogos de las obras

la convicción, en España y Portugal, de que es posible una épica del presente y una épica de la verdad [...]: no importan pues tanto las cuestiones neoaristotélicas, cuanto las necesidades políticas del imperio y la percepción de la existencia de una historia poetizable que ya es heroica antes de ser contada. A diferencia de cuanto ocurre en la poética italiana, y en contraste con la nación misera de Italia -el adjetivo es de Guicciardini- sobre cuyo presente no puede edificarse una visión heroica, los autores hispánicos dicen tener la convicción de vivir en un momento excepcional, que no cede a los clásicos. (107)

Hay que pensar, como ya se dijo, en la épica como una pieza más (junto con obras plásticas y otras muy variadas expresiones) al servicio de la representación del proyecto imperial. No había ningún inconveniente en poetizar hechos recientes y aun actuales, como hizo Ercilla. Explica Vega que mantuvieron como modelo a Virgilio, quien "trata del presente de Augusto cuando habla del pasado de Eneas"; pero que no renunciaron a Lucano, a quien apreciaron "por la misma razón por la que lo rechazaron los tratadistas europeos más apegados al aristotelismo" (Vega 107), es decir, por hacer historia en verso y por tratar hechos recientes. Ambas cualidades son puestas de relieve por los poetas como los aspectos del más alto valor de sus obras: tratan sobre la verdad, una verdad de la que no pueden apartarse porque serían desmentidos por otros testigos oculares de los mismos acontecimientos. A tal punto era apreciado el vínculo de la épica con la historia, que la fábula (esencial para Aristóteles y los renacentistas italianos) fue considerada por muchos como una "engorrosa necesidad" (114) exigida por el género, impuesta por los antiguos. 
¿Cuáles son las posiciones declaradas de los autores de nuestros preliminares? No todos se pronuncian sobre esto, pero en general hay un amplio consenso en la necesidad de escribir (si bien con la dulce cadencia de la poesía) historias verdaderas. Y son varios los autores que sienten la necesidad de justificar la presencia de la fábula, que viene entretejida con la historia misma. Dos de ellos se refieren a la fábula como una exigencia "obligada" para la poesía (uno de ellos casi la elude). Por último, y en contraste, Valverde se constituye en campeón de la fábula, si bien como artificio alegórico, cuya acción sustituye la real.

Juan de las Evas observa que las virtudes que pudieron admirar en santa Rosa sus contemporáneos, una vez muerta ella, "quedan en los libros escritas, si no muertas, a lo menos tibias; pero en estos cantos se reconocen vivas" ( $b$ 1r). Es decir, la materia del poema es la verdad histórica; y añade (según ya vimos) que esto mismo atribuyó san Ambrosio a Moisés, el cual compuso un bello cántico tras el paso del Mar Rojo para que con su suavidad y gusto los hebreos tuviesen memoria del hecho. Eso mismo, añade, hicieron Gregorio Nacianceno, Prudencio e Isidoro: escribir "en poética cadencia" las maravillosas historias de las Escrituras y también vidas de santos, "para que el más curioso hallase entre la diversión el adelantamiento, pues tal vez el que empieza a leer divertido acaba su tarea aprovechado" ( $(223 \mathrm{v})$. En todos los ejemplos que ofrece piensa en hechos históricos poetizados, y no considera, en cambio, su mezcla con episodios fabulosos. En un solo pasaje da la impresión de abrirse, de mala gana, a esta mezcla a la que alude apenas, sin que pueda decirse si se refiere o no a ella: "La variedad hermosa de historias y doctrinas con que esta obra se viste hace el más agradable pensil a los estudiosos, teniendo mucho que admirar en las flores que empiezan como halago en el entendimiento y acaban como frutos en la voluntad" ( $b$ 1v; el resaltado es mío). Para no mencionarla directamente, la incluye en una vaga enumeración ("historias y doctrinas"), y no parece prestar atención más que a aquello que acaba en "frutos de la voluntad", esto es, que la del lector se vea atraída por el ejemplo de la santa.

Pedro de la Peña tampoco se muestra partidario de la fábula, más propia de los antiguos, quienes para guiar a los hombres los "engañaban con la misma verdad, haciendo con novedad virtuoso el engaño" (e2 3v). No era novedad considerar los pasajes fabulosos de los poemas antiguos como un atractivo señuelo para atraer la atención y, con ello, ofrecer una enseñanza. Continúa Peña indicando que entre cristianos este artificio no es necesario, ya que resulta mejor, como "senda para la verdad, ella misma", como añade en el mismo pasaje. Y en su elogio a Oviedo y Herrera se empeña en mostrar que en su 
poema presenta la verdad "en su traje natural”, y que una pequeña dosis de fábula, a la que alude como de paso, es entretejida por el autor "con moderación y provecho" (e2 3v).

Miguel Núñez de Roxas habla de las "escogidas galas y vistosos matices con que hermosea" Oviedo y Herrera las acciones de santa Rosa, y añade que logró hacerlo

sin desviarse un punto de la obligación de bistoriador ni de los preceptos de poeta, pues si entretejió la historia de la ficción fue no confundiendo sino haciendo más deleitable la verdad, hermoseándola vistosamente, con bien apropriado si fabuloso traje, por no faltar a este tan preciso documento del Parnaso, que el violarle burló a Lucano, en el común sentir de los críticos, el crédito de las fatigas con que costeó su Farsalia. (c2 1v-2r; el resaltado es mío)

En efecto, los episodios fabulosos no afectan a la biografía de santa Rosa, porque quedan bien delimitados y son claramente distinguibles. Pero en el enunciado de Núñez de Roxas se ven dos estatutos bien diversos para cada uno de estos elementos. El que señala en primer lugar, como "obligación", consiste en hacer historia (con ello parece incurrir en un muy voluntario olvido, porque esto también le reprocharon los neoaristotélicos a Lucano). El segundo elemento, la fábula, aparece más bien como un requisito añadido por los críticos. Había, pues que "cumplir con la poesía” (Vega 113).

Fernando Carrillo de Córdova, por su parte, considera que se pueden admirar en el poema las hazañas de la santa limense, la cual luchó "en la civil guerra interna de las humanas pasiones, que con invencible esfuerzo sujetó, venciéndose a sí misma” ( $g 22 \mathrm{v})$; “entre la diáfana transparencia de los colores poéticos", asegura, "se deja ver la honesta desnudez de la verdad bistórica" ( $g 23$ r; el resaltado es mío). Pero el triunfo de la santa, que aún no había sido "colocado en su esfera por el débil vuelo de la Historia [o sea, las biografías], demandaba a la poética la remontada sublimidad de sus plumas [de Oviedo]" (g2 2v). Al hablar de la fábula, considera que el poeta no cayó en el defecto de Homero, de extenderla, con carácter alegórico, a lo largo de toda la obra (opinión sostenida también por Valverde) $)^{9}$ sino que, al igual que Virgilio "entretejió oportunamente la fábula en la serie de la obra” ( $b$ 1r), hizo lo propio con

9. Pero sorprendentemente, casi a continuación indica estar de acuerdo con Scaligero en que Homero no habría dado valor alegórico a toda su obra. 
los episodios de Vilcaoma y Yupanqui. Afirma que Oviedo y Herrera se ajustó a las reglas del arte, y hace una enumeración en la que no faltan sorpresas. Por ejemplo, dice que acertó el poeta "en la elección del asumpto, ni muy remoto ni muy moderno, en que erró Virgilio". Puesto a hablar de "reglas", silenciar a Lucano en este punto (criticado por la cercanía temporal de lo narrado) no puede sino responder a una técnica de distracción, porque el poema de Oviedo y Herrera relata acciones más cercanas a su tiempo que las que transmite el cordobés en Farsalia respecto del suyo. Pero en cambio reserva para Lucano otra crítica, la (supuesta) falta de invención.

Valverde es el que mayor distancia desea establecer entre su actividad de poeta y el oficio de historiador. Su apego a Aristóteles y a los neoaristotélicos es aquí absoluto, y sostiene de manera militante la necesidad de la fábula. Recuerda que Sócrates,

habiendo de ejercer aún cuando estaba para morir el oficio de poeta, no hallando a mano otra fábula que cantar, se ocupó en poner en metro las de Esopo: Enseguida reflexioné que para ser verdaderamente poeta no basta hacer discursos en verso, sino que es preciso inventar ficciones, y no ocurriéndoseme ninguna recurrí a las fábulas de Esopo y versifiqué las primeras que acudieron a mi memoria [en nota marginal indica "Plato. In Phaedone"; sigue la versión latina de Ficino]. Tan inescusable es en el poeta el ingenioso artificio de la fábula que ni la gravedad de Sócrates ni la hora ya inminente del morir pudieron dispensar en la ficción.

Remitiendo al Timeo de Platón, anuncia que la acción épica de su poema ocurre en el plano superior de la alegoría, que es el inteligible: el objeto del poema es tratar sobre "la fundación de un imperio de la fe y de la gracia en Perú por parte de la Virgen María, con milagros como instrumentos" (Valverde III v). Esto, de paso, sirve para "enunciar la acción y héroe unitarios" (Sabena 2014, 119), que desarrolla después en consonancia con la preceptiva renacentista. En cambio, los hechos narrados, o sea las acciones de los pastores que peregrinan de Chucuito a Copacabana, junto con las de los demás personajes del poema, corresponden al plano inferior, el sensible, que sirve para manifestar al primero. Esto le da plena libertad para desarrollar el relato ficcional como mejor le parezca. Por otra parte, la cercanía de los hechos, señala Sabena, no es sino un fenómeno que corresponde a una trama (la principal) que ocurre fuera del tiempo, o "en un tiempo providencial, parte del plan divino" $(2014,120)$. Y añade la autora que Valverde "pone todo el acento en la activi- 
dad de verosimilización poética -siguiendo en esto a Aristóteles y el Pinciano-, alejándose expresamente del oficio de historiador" (120).

Este es el aspecto de la teoría que parece más rico en posiciones por parte de los autores aquí convocados.

\section{FINAL}

Era de esperar que no apareciera ninguna "novedad absoluta" en nuestros preliminares, tal vez porque sus autores escriben bien entrado el siglo XVII (Valverde y sus acompañantes) y casi acabado este (Oviedo y los suyos). La revisión de sus enunciados nos ha permitido verificar formas variadas en que se desarrollaron algunas de las teorías relativas a la poesía épica, así como el modo en que se concretaron las tendencias de la época en los dos poemas que forman parte del repertorio épico más representativo del siglo XVII en el virreinato.

En relación con los tópicos abordados podemos decir que el furor poético es algo que nuestros autores celebran sin reservas, posiblemente a la sombra del Cisne de Carvallo; que la doble exigencia horaciana es admitida sin aportes significativos; que el estatuto de verdad histórica es altamente valorado (con la posición peculiar que vimos en Valverde); y que en ninguno de los autores aparece como problemática la cercanía de los hechos tratados (con la misma peculiaridad en el mismo poeta). Sí se registran algunas diferencias en relación con la fábula: hay quienes la celebran, otros que la admiten de buena o mala gana, y uno (Valverde) que se muestra aristotélico, si bien a su manera. Julia Sabena indica lúcidamente que este "ofrece un mosaico de autoridades como sostén de un poema que no sigue con rigurosidad las reglas aristotélicas para su conformación sino que practica una apropiación variada y desigual de las tradiciones que lo anteceden", y que "realiza una justificación laberíntica en lo que atañe a las elecciones relacionadas con el género" $(2014,116)$. Su prólogo es, sin embargo, de utilidad como registro de recepción de tradiciones teóricas.

Lo que parece claro es que tanto los preliminares como los dos poemas épicos constituyen un acceso a una sabia "república de letras", interesada en las teorías literarias, de cuya existencia apenas se sospechó hasta tiempos bastante recientes. El hecho de que haya autores que en ocasiones disimulen contradicciones con alguna pirotecnia retórica (de antología son las apreciaciones y los "olvidos" de Núñez de Rojas y Carrillo de Córdova en relación con aspectos de la poesía de Lucano) no disminuye el hecho de que conocen y manejan las teorías al uso. En tal república participan con pleno derecho, como iguales, españoles y americanos. 


\section{OBRAS CITADAS}

Aristóteles. Poética. Ed. trilingüe de V. García Yebra. Madrid: Gredos, 1974.

Avalle-Arce, Juan Bautista. La épica colonial. Pamplona: EUNSA, 2000.

Bramón, Francisco. Los sirgueros de la Virgen sin original pecado. Ed. Trinidad Barrera. Madrid: Iberoamericana/Frankfurt am Main: Vervuert, 2013.

Cacho Casal, Rodrigo. "Volver a un género olvidado: la poesía épica en el Siglo de Oro". Criticón 115 (2012): 5-10.

Carrillo de Córdova, Fernando. "Juicio del poema”. En Oviedo y Herrera, $g 1 \mathrm{v}-h 22 \mathrm{r}$.

Carvallo, Luis Alfonso. Cisne de Apolo. Medina del Campo: Juan Godínez de Millis, 1602.

Davis, Elizabeth. "Épica y configuración del canon en la poesía española del Siglo de oro". En torno al canon: aproximaciones y estrategias. Ed. Begoña López Bueno. Sevilla: Universidad de Sevilla, 2006. 317-32.

Eichmann, Andrés. "La Virgen Cerro de Potosí: ¿arte mestizo o expresión emblemática?". Revista de historia americana y argentina 42-43 (20072008): 37-59.

Eichmann, Andrés, y Joaquín Zuleta. "Edición y traducción de la Carta a lord Burghley de Pedro Sarmiento de Gamboa”. Hipogrifo 4.1 (2016): 23-42.

Evas, Juan de las. "Aprobación del doctor don Juan de las Evas, predicador de su majestad de los doce de número, capellán de honor y mayor del real convento de santa Isabel de esta corte, calificador de la suprema Inquisición y de sus juntas secretas, examinador sinodal del arzobispado de Toledo, teólogo de la nunciatura de España, etc.”. En Oviedo y Herrera, a2 $3 \mathrm{r}-b 22 \mathrm{r}$.

García Berrio, Antonio. Formación de la teoría literaria moderna: tópica boraciana en Europa. Madrid: Cupsa, 1977.

Genette, Gérard. Seuils. Paris: Seuil, 1987.

Gruzinski, Serge. Las cuatro partes del mundo: historia de una mundialización. México: FCE, 2010.

Horacio. Arte poética. Epístola a los pisones. Ed. Mario Frías Infante. La Paz: Altiplano, 2010.

Lancelotto, Secondo. L'oggi di'overo gli ingegni non inferior à passati. Parte seconda. Venecia: Guerigli, 1646.

López Pinciano, Alonso. Filosofía antigua poética. Madrid: Tomás Iunti, 1596. Manchón Gómez, Raúl. "El Carmen Paschale de Sedulio como poema alegórico: el simbolismo de los números". Auster 13 (2008): 101-14. 5 de mar- 
zo de 2018. <http://sedici.unlp.edu.ar/bitstream/handle/10915/10265/ Documento_completo_.pdf? sequence $=1>$.

Mazzotti, José Antonio. Lima fundida: épica y nación criolla en el Perú. Madrid: Iberoamericana/Frankfurt am Main: Vervuert, 2016.

Mújica Pinilla, Ramón. Rosa limensis: mistica, política e iconografía en torno a la patrona de América. Lima: IFEA/FCE/BCRP, 2001.

Nallim, Carlos Orlando. "El Cisne de Apolo de Carvallo y la inspiración poética”. Revista de literaturas modernas 4 (1965): 71-85.

Núñez de Roxas, Miguel. "Censura de don Miguel Núñez de Roxas, del consejo de su majestad, caballero de el orden de Santiago, doctor en ambos derechos en la universidad de san Marcos de la ciudad de Lima, etc.". En Oviedo y Herrera, $b 2$ 3r- $d$ 3v.

Ortega Sotomayor, Pedro de. "Aprobación del doctor don Pedro de Ortega Sotomayor, Arcediano de esta santa iglesia metropoliana de los Reyes, catedrático de prima de teología en la real Universidad y calificador del santo oficio”. En Valverde, $\mathbb{1 3}$ 1r.

Oviedo y Herrera, Luis Antonio. Vida de Santa Rosa de Santa María, natural de Lima y patrona del Perú: poema heroico. Madrid: García Infançón, 1711.

Peña, Pedro de la. "Parecer de el doctor don Pedro de la Peña, racionero de la santa iglesia catedral de la ciudad de Lima, catedrático de prima de sagrados cánones de la universidad de san Marcos y consultor del santo oficio de la Inquisición del Perú". En Oviedo y Herrera, e 2 1v- $f 23 \mathrm{r}$.

Pierce, Frank. La poesía épica del Siglo de Oro. Madrid: Gredos, 1968.

Platón. Ion o De la poesía. Trad. Mario Frías Infante. La Paz: Editorial G.U.M., 2014.

Prieto, Antonio. Coherencia y relevancia textual: de Berceo a Baroja. Madrid: Alhambra, 1980.

Puddu, Raffaelle. El soldado gentilhombre: autorretrato de una sociedad guerrera. Barcelona: Argos Vergara, 1984.

Quint, David. Epic and Empire: Politics and Generic Form from Virgil to Milton. Princeton: Princeton UP, 1992.

Ribera, Juan de. "Aprobación del muy reverendo padre maestro fray Juan de Ribera, del orden de nuestro padre san Agustín, catedrático de vísperas de teología en la real universidad de los Reyes y calificador del santo oficio". En Valverde II $\mathrm{r}-\mathrm{v}$.

Sabena, Julia. "Con voz heroica y épicos alientos: sobre el género y las filiaciones del Santuario de Nuestra Señora de Copacabana en el Perú (1641) de Fernando de Valverde". Zama 6 (2014): 115-27. 
Sabena, Julia. "Algunas observaciones en torno al gongorismo peruano: el Santuario de Fernando de valverde". Revista de Crítica Literaria Latinoamericana 83 (1er semestre de 2016): 61-79.

Valverde, Fernando de. Santuario de nuestra Señora de Copacabana en el Perú. Lima: Luis de Lyra, 1641.

Vega, María José. "Idea de la épica en la España del Quinientos". La teoría de la épica en el siglo XVI (España, Francia, Italia y Portugal). Pontevedra: Academia del Hispanismo, 2010. 103-35.

Vega, María José, y Lara Vilà. "Preliminares". La teoría de la épica en el siglo XVI (España, Francia, Italia y Portugal). Pontevedra: Academia del Hispanismo, 2010. 13-19.

Vélez Marquina, R. Elio. Rosa de Indias: discursividad criolla y representación simbólica de la comunidad de Lima en Vida de Santa Rosa de Santa María del Conde de la Granja (1711). 2010. Lima: Pontificia Universidad Católica del Perú, tesis de Licenciatura. 20 de mayo de 2018. < http://tesis.pucp. edu.pe/repositorio/handle/20.500.12404/462>.

Vélez Marquina, R. Elio. "Transformaciones americanas de la épica culta: hagiografía y posicionamiento criollo en Vida de santa Rosa". Viajeros, crónicas de Indias y épica colonial. Eds. Mariela Insúa y Jesús Menéndez Peláez. New York: IDEA, 2017. 141-94.

Vilà i Tomàs, Lara. Épica e imperio: imitación virgiliana y propaganda politica en la épica española del siglo XVI. 2001. Universidad Autónoma de Barcelona, tesis doctoral.

Vilà, Lara. "Fama y verdad en la épica quinientista española: el virgilianismo político y la tradición castellana del siglo XV". Studia Aurea 4 (2010): 1-35.

Wagner, Klaus. "Los contrafacta a lo divino en la literatura de los siglos de oro". Boletín de la Real Academia Sevillana de Buenas Letras 29 (2001): 75-83. 